\title{
PENINGKATAN KEMAMPUAN MOTORIK KASAR ANAK USIA DINI MELALUI PEMBELAJARAN GERAK TARI AYAM
}

\author{
Triana Indrawati ${ }^{1}$, Nabila Aulia Rahmah ${ }^{2}$ \\ ${ }^{12}$ Institut Agama Islam Negeri Pekalongan \\ trianaindrawati@gmail.com
}

\begin{abstract}
Chicken Dance Motion is a dance movement with the imagination like being a Chicken who is looking for food, walking, jogging, and so forth. Motion as the main ingredient in dance, is used as a medium to express ideas of what they think and feel. Chicken dance movements can improve the gross motor development of children. Motor Development means the development of controlling physical movements through coordinated nerve center, nerve and muscle activities. This study aims to describe the pre-cycle conditions of chicken dance learning in B1 group children and explain whether the method of chicken dance learning can improve the development of gross motor skills of young children. This type of research is a classroom action research conducted collaboratively between researchers and teachers. The study was conducted in two cycles. The research subjects were children of group B1 TKIT Mutiara Hati Petarukan Pemalang. The results showed that there was an increase in children's gross motor development through chicken dance movements in the B1 group TKIT Mutiara Hati Petarukan Pemalang
\end{abstract}

Keywords: gross motor skills, early childhood, and dance moves.

\begin{abstract}
Abstrak
Gerak Tari Ayam merupakan gerakan menari dengan berimajinasi sperti menjadi seekor Ayam yang sedang mencari makan, sedang berjalan, berlari-lari kecil, dan lain sebagainya. Gerak sebagai bahan utama dalam tari, digunakan sebagai media untuk mengungkapkan ide dari apa yang mereka pikitkan dan rasakan. Gerak tari ayam dapat meningkatkan perkembangan motorik kasar anak. Perkembangan Motorik berarti perkembangan pengendalian gerakan jasmaniah melalui kegiatan pusat syaraf, urat syaraf, dan otot yang terkoordinasi. Penelitian ini bertujuan untuk mendeskripsikan kondisi prasiklus pembelajaran gerak tari ayam anak kelompok B1 serta menjelaskan apakah metode pembelajaran gerak tari ayam dapat meningkatkan perkembangan motorik kasar anak usia dini. Jenis penelitian yang digunakan adalah penelitian tindakan kelas yang dilakukan secara kolaboratif antara peneliti dengan guru. Penelitian dilaksanakan dalam dua siklus. Subyek penelitian adalah anak kelompok B1 TKIT Mutiara Hati Petarukan Pemalang. Hasil penelitian menunjukkan bahwa terdapat peningkatan perkembangan motorik kasar anak melalui gerak tari ayam pada kelompok B1 TKIT Mutiara Hati Petarukan Pemalang.
\end{abstract}

Kata Kunci: Motorik Kasar; Anak Usia Dini, dan Gerakan Tari.

\section{PENDAHULUAN}

Perkembangan pada anak usia dini mencakup perkembangan fisik dan motorik, kognitif, sosial emosional, dan bahasa. Usia anak pada masa ini merupakan fase fundamental yang akan menentukan kehidupannya dimasa datang, sehingga kita harus memahami perkembangan anak usia dini khususnya perkembangan fisik dan motorik (Suryana, 2016). Berbagai stimulus dibutuhkan untuk tumbuh kembang anak (Padilah dan Novianti, 2019). Perkembangan berkaitan dengan perubahan kualitatif dan kuantitatif. Ia dapat didefinisikan sebagai deretan progresif dari 
perubahan yang teratur dan koheren. "Progesif" menandai bahwa perubahannya terarah, membimbing mereka maju bukan mundur. "Teratur" dan "Koheren" menunjukkan adanya hubungan nyata antara perubahan yang terjadi dan yang telah mendahului atau yang akan mengikutinya (Zarkasih, dkk; 1978).

Fisik dikatakan berkembang jika mengalami perubahan pada ukuran kaki, tangan dan badan yang semaki membesar, memanjang, melebar atau semakin tinggi. Perkembangan motorik adalah proses yang sejalan dengan bertambahnya usia secara bertahap dan berkesinambungan, dimana gerakan individu meningkat dari keadaan sedeerhana, tidak terorganisir, dan tidak terampil, kearah penguasaan keterampilan motorik yang kompleks dan terorganisasi dengan baik. Perkembangan Motorik berarti perkembangan pengendalian gerakan jasmaniah melalui kegiatan pusat syaraf, urat syaraf, dan otot yang terkoordinasi. Sebelum perkembangan tersebut terjadi, anak akan tetap tidak berdaya (Suryana, 2016). Masih banyak orang tua atau pendidik anak usia dini yang belum menyadari kaitan antara pendidikan anak usia dini dengan ketrampilan motorik anak (Hasanah, 2016); (Anggraini, 2019). Mulyasa (2012) mengungkapkan bahwa tidak ada persamaan antara perkembangan anak yang satu dengan anak yang lain. Diantara anak tersebut tidak ada yang sama persis, entah dalam perkembangan motorik maupun fisiknya. Kemampuan pada anak baik secara fisik maupun secara motorik berkembang sesuai dengan usia dan terdapat tahapan-tahapannya. Pertama, berkembang secara normal. Kedua, perkembangannya mengalami suatu hambatan. Hal ini menyebabkan perkembangan fisik maupun motorik anak cenderung dapat diramalkan. Selain hal tersebut perkembangan social anak pun perlu diperhatikan (Khoiruzzadi, 2020).

Gerakan yang lebih fokus dan terarah seperti menggunting, membatik lebih mengarah ke kemampuan motorik halus (Rofiah dan Mangkuwibawa, 2020). Kemampuan bergerak dimana mempergunakan otot besar secara keseluruhan anggota tubuh dan didasari oleh tingkat kematangan anak menurut Suryana (2016) disebut sebagai kemampuan motorik kasar. Contoh dari kemampuan tersebut diantaranya adalah kemampuan untuk dapat berlari, menendang, duduk. Selain itu juga keterampilan anak untuk naik turun tangga, berjalan, berlari, dan melompat. Bermain menggunakan alat simpai juga mampu meningkatkan keterampilan anak dalam hal motorik kasarnya (Zahroh, dkk). Koordinasi dalam kemampuan motorik anak memuat beberapa faktor, yaitu faktor keseimbangan, ketahanan tubuh, kelenturan, ketangkasan, kecepatan, dan kekuatan dari si anak tersebut.

Dalam mengkoordinasikan kemampuan anak, keterampilan koordinasi motorik kasar pada anak dibagi menjadi tiga. Pertama, keterampilan lokomotor. Keterampilan menggerakkan tubuh, contohnya: berlari, melompat, berguling, menderap, berjalan, menjatuhkan diri, dan 
meluncur. Ketrampilan ini mensuport kesadaran persepsi motorik. Kesadaran ini meliputi kesadaran terhadapr diri, ruang (spasial), waktu, arah, serta pendengaran. Hal ini dapat terlihat ketika anak beusaha meniru gerakan yang diperagakan orang lain. Kedua, ketrampilan nonlokomotor. Ketrampilan ini meliputi pergerakan anggota tubuh dimana anggota tubuh yang dimaksud hanya diam, tidak berubah posisi atau tempat. Ketrampilan ini dikaitkan keseimbangan dalam tubuh. Contoh dari ketrampilan ini adalah kegiatan ayunan, merentang, bergoyang, membungkuk, memutar, dan mendorong. Terakhir, ketrampilan memanipulasi. Ketrampilan ini merupakan kegiatan mengontrol gerakan otot yang kecil, degan gerakan yang terbatas. Terbatas, hanya dibatasi pada bagian tubuh tangan serta kaki. Selain memanipulatif, ketrampilan ketiga ini juga disebut ketrampilan memproyeksi. Contoh gerakan memanipulasi adalah menggenggam, menulis, menggunting, dll. Sedangkan contoh kegiatan proyeksi adalah melambungkan bola, memukul, serta menarik.

Rahyubi (2012) menyatakan terdapat beberapa faktor yang mempengaruhi perkembangan kemampuan motorik pada seseorang. Pertama, faktor pada sistem saraf pada individu tersebut. Kedua, keadaan fisik seseorang. Ketiga, motivasi yang dimiliki oleh seseorang. Keempat, lingkungan yag kondusif. Kelima, aspek psikologis. Keenam, faktor usia. Ketujuh, faktor jenis kelamin. Terakhir, faktor bakat dan potensi. Kemampuan motorik berkembang seiring dengan adanya pertambahan usia. Perkembangan ini berjalan sesuai tahapan serta adanya kesinambungan. Gerakan-gerakan yang dimiliki individu berkembang sehingga menjadi lebih terorganisisr, terampil, terarah, hingga mencapai penguasaan kemampuan motorik yang baik.

Menurut Mulyani (2016), anak usia TK dapat melakukan gerakan yang penuh dengan kendali serta terorganisir sesuai dengan pola. Gerakan ini misalnya, posiis tangan dapat dengan santai terjungkai, gerakan tungkai dan kaki saat melangkah, saat berdiri tubuh lebih tegak, dan lain sebagainya. Pola yang terkendali dan teroganisisr tersebut membuat anak lebih mudah merespon berbagai keadaan. Saat itulah, ketrampilan motorik kasar dan halus pada anak dapat berkembang dengan pesat. Ketrampilan motorik dapat ditingkatkan melalui permainan (Putri dan Prima, 2020). Anak usia TK biasanya aktif, hal ini membuat mereka menguasai tubuhnya dengan baik. Selain itu, biasanya mereka memiliki dunia sendiri, berkegiatan sendiri pula. Pada masa ini, otot besar mereka berkembang dengan baik daripada melakukan kontrol pada bagian kaki dan tangan. Kegiatan rumit belum bisa dilaksanakan pada usia ini. Salah satu contoh gerakan sederhana yang dapat dilakukan pada masa ini antara lain gerak tari. Pengalaman dalam belajar dengan menyenangkan dapat diperoleh dengan tari (Akbar, 2018).

Gerak tari merupakan salah satu . Bahan utama dalam tari yaitu gerak. Gerak merupakan media untuk mendeskripsikan suatu ide yang sedang dipikirkan dan dirasakan. Dimana hal ini 
merupakan suatu hal yang tidak mudah. Ada dua aspek penting dalam tari, yaitu aspek gerak dan aspek irama. Gerak tari yang diolah dengan baik dapat menjadi sesuatu yang menarik. Dimana hasil gerak tari bukan semata hanya meniru. Proses mengubah gerak nyata menjadi gerak tari dikenal dengan istilah oproses penghalusan (menstilir/stilisasi), dan proses perombakan (distori). Salah satu gerak tari yag dapat dilakukan anak usia dini adalah gerak tari ayam.

Gerak Tari Ayam yaitu menari dengan berimajinasi seperti menjadi seekor Ayam yang sedang mencari makan, sedang berjalan, berlari-lari kecil, dan lain sebagainya. Imajinasi anak akan gerakan perlu dikembangkan, diantaranya melalui komunikasi. Dengan adanya komunikasi yang intens, dapat memberikan kesempatan bagi anak-anak mengungkapkan ekspresi-ekspresi gerak secara wajar. Gerakan tari Ayam (tari kreasi) musik tariannya bisa dengan musik tradisional akan tetapi yang ceria agar anak senang dalam latihan setiap gerakannya.

Gerak tari ayam juga dapat mempengaruhi perkembangan motorik kasar anak usia dini. Hal ini karena kemampuan motorik kasar anak dapat dipengaruhi oleh suatu gerak. Gerakangerakan yang mencakup anggota tubuh secara keseluruhan, gerak yang hanya ditempat saja atauopun yang berpindah tempat. Kegiatan bergerak tersebut antara lain, ketika si anak berjalan, anak meloncat, ataupun anak berenang, dan lain sebagainya. Gerak tari ayam merupakan metode atau kegiatan yang dapat meningkatkan perkembangan motorik kasar anak.

Penelitian Febrialismanto (2017) menggambarkan kemampuan motorik kasar Anak Usia 4-5 Tahun di Taman Kanak-kanak kecamatan Bangkinang kabupaten Kampar provinsi Riau. Fokus peneliti dalam penelitian ini yaitu pada kegiatan-kegiatan anak usia dini yang mengarah pada kemampuan motorik kasar dan melakukan gerakan yang menirukan segala sesuatu disekitar anak seperti menirukan binatang, pohon, htertiup angin, pesawat terbang dan lain sebagainya. Penilitian ini dilaksanakan di Taman Kanak-kanak kecamatan Bangkinang kabupaten Kampar provinsi Riau. Hasil dalam penelitian ini adalah pada Kec.Bangkinang, Kab.Kampar terdapat 72,78\% anak usia 4-5 tahun yang berkembang sesuai harapan (BSH). $85,17 \%$ anak masuk dalam kategori berkembang sangat baik. Indikator yang paling menonjol adalah anak bermain di luar kelas dengan menggunakan alat. Anak melakukan lemparan sesuatu yang terarah serta melakukan gerakan antisipasi merupakan indicator dengan nilai yang paling rendah.

Penilitian Maria Hidayanti (2013) mengenai peningkatan kemampuan motorik kasar anak melalui permainan bakiak. Fokus peneliti dalam penilitian ini yaitu meningkatkan kemampuan motorik kasar melalui permainan bakiak. Penelitian ini dilaksanakan pada anak Kelompok B di TK Sanggah Winayah kabupaten Majalengka. Hasil penelitian yang diperoleh yaitu permainan 
bakiak dapat menjadikan kemampuan motorik kasar pada anak mengalami peningkatan. Hal ini dapat dilihat dari rerata skor kemampuan motorik kasar anak. Pada tindakan awal terdapat peningkatan sebesar $11,29 \%$. Pada siklus I menuju siklus II kemampuan motorik kasar anak meningkat sebesar $16,98 \%$.

Ratu Tuti Alawiyah meneliti peningkatan ketrampilan motorik kasar melalui permainan tradisional Banten (2014). Fokus peneliti yakni mengenai upaya meningkatkan ketrampilan motorik anak. Usia anak dalam penelitian ini adalah 4-5 tahun. Ketrampilan motorik dalam penelitian ini ditingkatkan menggunakan permainan, yakni bermain Aviciena Anye. Permainan ini merupakan permainan tradisional asli Banten. Pada siklus pertama, kemampuan motorik kasar anak usia dini meningkat sebesar 70,2\%. Pada siklus 2, kemampuan motorik meningkat sebesar $88,89 \%$. Kemampuan motorik kasar anak meningkat, respon anak positif terhadap permainan Aviciena Anye. Peneliti merekomendasikan bahwa permainan Aviciena Anye menjadi salah satu solusi dalam meningkatkan kemampuan motorik kasar pada anak usia dini.

Apriloka (2020) meneliti ketrampilan motorik menggunakan pre-eksperimen desain. Apriloka menggunakan One Group Pretest Posttest. Permainan kreatif digunakan peneliti kepada anak dengan tujuan untuk latihan dan pembiasaan. Permainan kreatif dalam penelitian ini dilaksanakan anak dengan pengelompokkan jenis kelamin. Tidak terdapat perbedaan ketrampilan motorik anak berdasarkan jenis kelaminnya.

Arwati (2019) melakukan penelitian quasi-eksperimen metode gerak dan lagu di PAUD Kasih Ibu. Hasil peneiltian menunjukkan kemampuan kosakataanak dalam menggunakan Bahasa Ingrgriss sebelum adanya perlakuan berada pada kategori mulai berkembang (MB). Setelah adanya perlakuan, pada kelas eksperimen menunjukkan rata-rata anak berada pada kategori berkembang sesuai harapan (BSH). Sedangkan kelas kontrol hanya mencapai kategori mulai berkembang (MB).

Perkembangan motorik kasar pada usia dini sangat penting di saat anak sedang berada pada masa pertumbuhannya. Dalam mengembangkan motorik kasar anak dapat dilakukan sejak anak berada diusia golden age dimana pada masa itu anak sangat tajam ingatannya dan sangat aktif dalam bergerak. Layaknya seorang anak mendapatkan kesempatan beraktifitas fisik sehingga kemampuan motorik dapat berkembang dengan baik. Aktifitas fisik yang dapat dilakukan antara lain dengan menggerakkan anggota tubuhnya secara keseluruhan, seperti menari, gerak senam dan lain sebagainya. Berdasarkan standar kurikulum AUD (2013) tingkat pencapaian perkembangan motorik kasar anak usia dini usia (usia TK) yaitu. Yang pertama, anak mampu melaksanakan suatu gerakan yang terkoordinasi pada tubuh yang berguna untuk melatih anak menjadi lincah, lentur, dan seimbang. Kedua, anak mampu mengkoordinasikan gerak yang 
melibatkan anggota tubuh (mata, kaki, tangan, dan kepala) ketika melakukan olahraga senam atau melakukan tari. Ketiga, anak mampu bermain menggunakan aturan dalam suatu permainan fisik. Keempat, anak dalam menggunakan tangan dan kaki menjaid terampil. Terakhir, anak mampu menjaga kebersihan diri sendiri.

Upaya yang harus dilakukan para pendidik dan orang tua dalam peningkatan kemampuan motorik kasar anak yaitu melakukan gerak tari, gerak lagu yang tidak monoton karena masih banyak sekolah yang memberikan pembelajaran untuk meningkatkan motorik kasar masih monoton dan membuat anak cepat bosan yang mengakibatkan perkembangannya tidak optimal karena melalui kegiatan yang menarik anak lebih bersemangat dan berantusias untuk melakukan kegiatan yang disampaikan oleh guru dan orang tua jika dirumah. Pembelajaran gerak tari ayam pada anak usia dini dilakukan secara aktif, kreatif dan menyenangkan, karena dengan cara tersebut dapat memberi pengalaman belajar pada anak sesuai dengan perkembangannya.

Pemberian pembelajaran gerak tari ayam di sekolah membuat menjadi aktif dan memiliki rasa keterlibatan. Selain itu, manfaatnya juga bisa bergerak sesuai irama dan bisa melakukan gerak tari ayam yang sederhana dengan sempurna. Untuk mendukung terlaksananya metode pembelajaran gerak tari ayam ini maka pembelajaran tari akan diterapkan di kelompok B1 dengan tema tari kreasi atau tari ayam. Tari ayam akan membuat anak berimajinasi atau berperan menjadi seekor ayam yang sedang mencari makan, berjalan dan juga menirukan suara ayam. Dengan demikian, diharapkan dapat meningkatkan perkembangan motorik kasar anak. Dalam hal ini meliputi kemampuan bergerak sesuai irama, bergerak dengan menirukan binatang ayam seperti ayam yang hendak terbang, ayam yang sedang berjalan, ayam yang sedang mencari makan, berjalan ditempat, jalan samping kanan dan kiri, dan jalan maju mundur.

Berdasarkan penjelasan sebelumnya maka rumusan masalah yang akan diteliti adalah. Apakah kegitan belajar anak usia dini melalui gerak tari ayam mampu mengembangkan kemampuan motorik kasar pada anak usia dini di kelompok B TKIT Mutiara Hati Petarukan Pemalang?. Bagaimana perkembangan motorik kasar anak usia dini di kelompok B TKIT Mutiara Hati pada tahap pra-siklus?.

\section{METODE PENELITIAN}

Penelitian ini merupakan penelitian tindakan kelas kolaboratif. Penelitian tindakan kelas merupakan sutau penelitian yang pelaksananya seorang guru itu sendiri sebagai peneliti atau bisa jadi bekerjasama dengan peneliti lain dan dilaksanakan di kelas atau di sekolah dimana bertujuan untuk meningkatkan hasil serta proses pembelajara (Arikunto, 2011). Peneliti memilih TKIT Mutiara Hati Kecamatan Petarukan Kabupaten Pemalang yang terletak di jalan garuda 
kecamatan petarukan kabupaten pemalang sebagai tempat penelitian. Subjek penelitian ini yaitu 24 anak kelompok B1 di TKIT Mutiara Hati Kecamatan petarukan Kabupaten Pemalang. Data dalam penelitian ini dikumpulkan menggunakan wawancara, observaasi, serta dokumentasi.

Model penelitian yang digunakan adalah teori milik Kemmis dan Taggart. Kemmis dan Taggart menyatakan bahwa siklus dalam suatu penelitian tindakan kelas terbagi menjadi beberapa tahapan kegiatan. Tahapan dalam satu putaran siklus terdiri dari tahap perencanaan, tahap tindakan, tahap observasi, dan tahap refleksi (Kardiawarman, 2000). Tahap yang pertama, tahap perencanaan dalam penelitian ini meliputi kegiatan penyusunan Rencana Pelaksanaan Pembelajaran Harian penyusunan (RPPH). Peneliti dalam penyusunan RPPH ini dengan menyesuaikan kondisi di sekolah sehingga pelaksanan kegiatan pembelajaran yang dilaksanakan di sekolah tidak terganggu. Tindakan adalah guru maupun peneliti melaksanakan kegiatan sesuai dengan skenario yang telah dibuat dan perangkat RPPH yang telah disiapkan. RPPH dilaksanakan di lapangan secara terbuka dan fleksibel jika terjadi adanya suatu perubahan. Peneliti dan guru bersama-sama mengobservasi pada setiap tahap dalam setiap siklus penelitian. Hasil dari observasi meliputi, bagaimana tindakan yang dilaksanakan guru dan peneliti, hal-hal apa saja yang terjadi selama pelaksanaan dalam setiap siklus, hasilnya seperti apa, situasinya bagaimana serta hambatan apa yang terjadi di lapangan. Kegiatan yang dilakukan peneliti pada tahap terakhir yakni, tahap refleksi. Pada tahap ini peneliti melakukan kajian dan pertimbanganpertimbangan pada setiap tindakan yang telah dilaksanakan. Peneliti mempertimbangkan apa yang perlu diperbaiki pada siklus berikutnya dengan melihat poin-poin yang masih lemah dan kurang sehingga memerlukan tindakan perbaikan.

Berikut ini adalah prosedur penelitian tindakan penelitian yang akan dilakukan peneliti, yaitu sebagai berikut: 
Gambar 1. Siklus Penelitian Tindakan Kelas

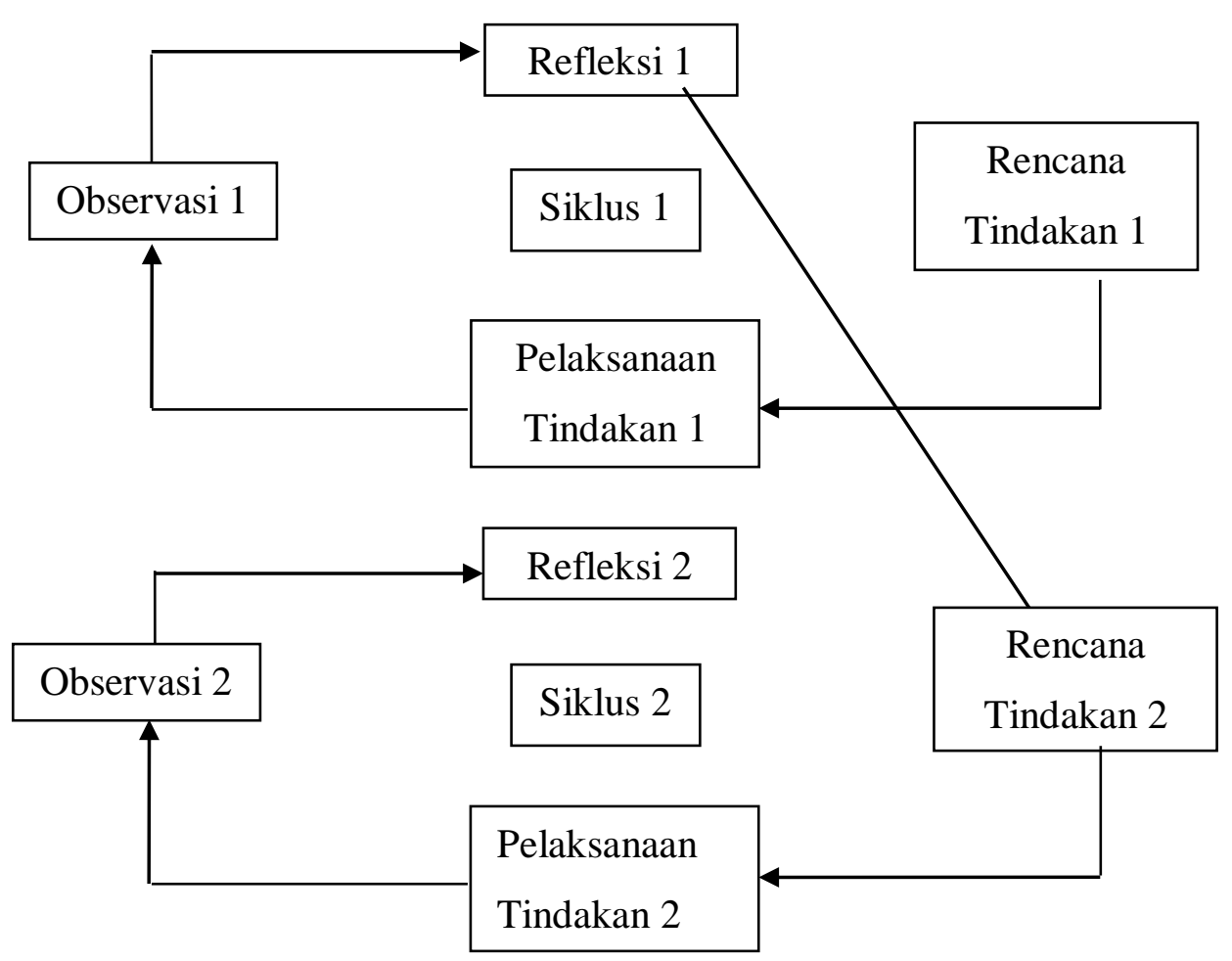

Teknik analisis data menggunakan deskriptif kuantitatif dan kualitatif. Peneliti menggunakan metode analisa data yang terbagi menjadi dua yaitu analisis kuantitatif deskriptf untuk melihat peningkatan perkembangan motorik kasar anak. Analisis ini disajikan dalam bentuk prosentase yang diketahui melalui penilaian lembar observasi peserta didik serta hasil wawancara peserta didik. Analisis kualitatif deskriptif yaitu data berupa deskripsi yang menggambarkan data dari hasil pengamatan pelaksanaan pembelajaran tari ayam saat kegiatan pembelajaran berlangsung.

\section{HASIL PENELITIAN DAN PEMBAHASAN}

Hasil observasi awal penelitian, peneliti menemukan bahwa kemampuan motorik kasar yang dimiliki oleh anak kelompok B1 di TKIT Mutiara Hati Petarukan masih belum optimal. Jika kemampuan motorik kasar anak ini diabaikan perkembangannya , anak menjadi pasif dalam berkegiatan jasmani dan beranggapan kegiatan tersebut tidak menarik dan membosankan (Novitasari, dkk; 2019)Hasil observasi pada awal pembelajaran anak membentuk barisan di depan kelas melakukan gerakd an lagu sambil mnenggerakkan kaki dan tangan. Dapat dianalisi, yang pertama bahwa anak menunjukkan mengalami adanya kesulitan dalam melakukan kombinasi gerakan secara bersamaan pada kaki dan tangan. Kedua, anak masih mengalami kesulitan jika disuruh jalan dengan menggunakan beberapa variasi, contohnya ketika melakukan jalan di tempat, jalan bergerak kanan dan kiri, maju dan mundur dengan adanya kombinasi 
gerakan kaki dan tangan. Ketika guru melakukan gerakan contoh, yakni guru bertepuk tangan sambil jalan di tempat. Beberapa anak hanya terdiam melihat dan mendengar instruksi dari guru. Tubuhnya hanya diam, tidak ada gerakan kaki dan tangan. Beberapa anak ingin maju ke depan dan beberapa anak ingin mundur ke belakang, ada juga anak yang hanya ingin bertepuk tangan saja.

Tahap awal penelitian (pra siklus) guru dan peneliti memberikan pembelajaran mengenai gerak tari. Gerak tari pada tahap ini belum diiringi musik. Pembelajaran pada tahap awal ini bertujuan supaya anak mampu mengenali dan memiliki pengetahuan mengenai gerak dan tari. Gerakan dasar yang diajarkan adalah anak berjalan di tempat, kemudian dua tangan diletakkan pada bagian pinggang, sedangkan bagian kepala menoleh ke sebelah kanan dan kiri.

Selanjutnya, guru dan peneliti mengajarkan anak untuk menggerakkan tangan sebelah kanan dan kiri ke atas ke bawah menirukan gerakan sayap ayam. Gerakan ini diiringi gerakan berjalan. Berjalan yang terkoordinasi, maju dan mundur, ke sebalah kanan dan kiri. Hal ini bertujuan seperti menirukan ayam yang sedang mengepakkan sayapnya. Kemudian melakukan gerakan seperti ayam yang sedang mencari makan dengan tangan kanan dan kiri berada di depan mulut lalu berjalan ke kanan dan ke kiri lalu badan di bungkukkan ke bawah seperti ayam sedang mencari makanan.

Gerakan selanjutnya tangan kanan dan kiri seperti menggulung benang sambil badannya putar kanan dan kiri sambil membungkukkan badan. Gerakan selanjutnya tangan kanan dan kiri di ayunkan ke kanan dan kiri secara bersamaan sambil melangkah ke samping. Gerak dan tari ini mengikuti ritme perhitungan angka satu, dua, tiga, dan empat. Gerak dan tari ini dilaksanakan terus menerus hingga keseluruhan anak mampu memahami dan meniru. Pada bagian akhir, setiap setiap anak melakukan pengulangan gerakan awal hingga mengayunkan tangan ke kanan dan kiri secara bersamaan. Tidak lupa anak diajari salam untuk menutup gerak dan tari ayam. Dari peserta didik berjumlah 24 anak yang berangkat hanya 16 anak, dikarenakan 8 anak yang tidak masuk sudah izin terlebih dahulu pada guru kelas untuk tidak berangkat sekolah selama KBM berlangsung sampai penerimaan rapot dengan alasan masing-masing. Selama tahap ini, 50\% anak berada pada kategori mulai belum berkembang (BB). 43,75\% anak berada pada kategori mulai berkembang (MB), dan sisanya 6,25\% berada pada kategori berkembang sesuai harapan (BSH).

Melihat kondisi pada tahap awal, guru dan peneliti melanjutkan tindakan ke siklus 1 . Harapannya kemampuan motorik kasar anak usia dini dapat meningkat. Gerak tari ayam ini diharapkan memiliki pengaruh pada anak kelompok B1 di TKIT Mutiara Hati Petarukan sehingga kemampuan motorik kasar anak terdapat peningkatan. Pelaksanaan siklus I 
dilaksanakan sebanyak 2 kali pertemuan. Hasil tindakan pada siklus 1 menunjukkan bahwa setengah subyek penelitian masuk kategori berkembang sesuai harapan (BSH), sedangkan setengahnya lagi masuk pada kategori mulai berkembang (MB). Nampak perbedaan pada tahap sebelumnya yakni sudah tidak terdapat anak pada kategori belum berkembang (BB).

Berdasarkan hasil pengamatan terhadap pelaksanaan pertemuan pertama siklus I anak mulai tertarik dengan kegiatan Tari Ayam, mereka mulai mengalami peningkatan dalam kemampuan Motorik Kasar walau hanya beberapa anak saja. Tahap refleksi, guru dan peneliti membahas dan mereview kegiatan sebelumnya. Terdapat beberapa permasalahan yang ditemukan. Antara lain, yang pertama, beberapa anak bergerak sesuka hati tanpa memperdulikan contoh yang diberikan. Kedua, terdapat anak yang belum mampu menyesuaikan gerakan dengan musik. Ketiga, kurangnya konsentrasi anak ketika melakukan gerak tari ayam membuat anak menjadi lupa akan urutan gerakan tarinya. Bahkan, beberapa anak membuat keributan dan berbicara sendiri.

Guru dan peneliti menyepakati hasil refleksi pada siklus 1. Sebagai solusi atas permasalahan pada siklus satu, yang pertama pelaksanaan gerak tari ayam akan diulangi sampai anak bisa walaupun terdapat kelonggaran gerakan. Anak yang sudah hafal dan lancar gerak tari ayam dijadikan sebagai contoh dengan diletakkan pada barisan paling depan. Hal ini bertujuan yang lain dapat mencontoh dari belakangnya. Jika ada anak yang salah, peneliti akan memberi peringatan cukup secara lisan. Peneliti akan memberikan peringatan dan memisah posisi anakanak yang suka membuat ribut dan berbicara sendiri, supaya tidak mengganggu konsentrasi anak yang lain.

Kemampuan motorik kasar anak pada kelompok B1 di siklus 1 ini menunjukkan adanya peningkatan. Peningkatan kemampuan motorik kasar anak terjadi dengan rincian sebagai beirkut. Sebesar 31,25\% anak berada pada kategori berkembang sangat baik (BSB). 50\% anak berada pada kategori berkembang sesuai harapan (BSH). Sisanya, 18,25\% anak berada pada kategori mulai berkembang (MB). Dikarenakan belum mencapai target penelitian yakni adanya $75 \%$ anak berada pada kategori berkembang sangat baik (BSB), peneliti melanjutkan ke siklus II.

Pembelajaran gerak tari ayam pada siklus ini fokus terhadap keaktifan. Anak diharapkan lebih aktif. Hasil refleksi pada tahap sebelumnya diterapkan. Mulai dari peringatan berupa instruksi lisan dari peneliti sampai posisi anak pada saat menari. Instruksi secara lisan hanya ketika anak lupa beberapa gerakan. Harapannya pada siklus II ini, terdapat peningkatan kemampuan motorik kasar anak melalui gerak tari ayam yang sesuai dengan target peneliti.

Siklus II mampu terlaksana dengan baik sesuai dengan harapan. Terdapat 81,25\% anak berada pada kategori berkembang sangat baik (BSB). Kategori ini meningkat sebesar 50\%. 
Peningkatan kemampuan motorik kasar anak usia dini cukup signifikan. Hal ini melebihi target peneliti yakni diatas $75 \%$. 6,25\% anak berada pada kategori berkembang sesuai harapan (BSH). Pada kategori ini persentasenya tetap, tidak mengalami kenaikan atau penurunan. Sisanya sebesar 12,5\% anak berada pada kategori mulai berkembang (MB). 0\% anak berada pada kategori belum berkembang (BB) dibandingkan pada saat awal penelitian terdapat $50 \%$ anak belum berkembang (BB). Alasan ini digunakan peneliti untuk menghentikan atau tidak melanjutkan siklus selanjutnya.

Pada akhir pembelajaran siklus II, anak mampu memergakan gerak tari ayam dengan lancar dan terstruktur dengan baik. Beberapa anak yang berada pada kategori belum berkembang diawal, mulai mampu menyesuaikan diri an melakukan gerak dan tari dengan baik. Anak yang pada awalnya berbicara sendiri dan mengganggu kosentrasi temannya, mampu berubah mengikuti gerak dan tari ayam dengan baik.

Penyajian hasil penelitian berdasarkan observasi peneliti secara lengkap dapat dilihat pada tabel berikut ini.

Tabel 1.

Perbandingan Rekapitulasi Motorik Kasar pada Pra Tindakan, Siklus I, dan Siklus II

\begin{tabular}{cccccccc}
\hline & \multicolumn{3}{c}{ Pratindakan } & \multicolumn{2}{c}{ Siklus I } & \multicolumn{2}{c}{ Siklus II } \\
\cline { 2 - 7 } NO & Kriteria & $\begin{array}{c}\text { Jumlah } \\
\text { Anak }\end{array}$ & Presentase & $\begin{array}{c}\text { Jumlah } \\
\text { Anak }\end{array}$ & Presentase & $\begin{array}{c}\text { Jumlah } \\
\text { Anak }\end{array}$ & Presentase \\
\hline 1. & BSB & - & - & 5 & $31,25 \%$ & 13 & $81,25 \%$ \\
2. & BSH & 1 & $6,25 \%$ & 8 & $50 \%$ & 1 & $6,25 \%$ \\
3. & MB & 7 & 43,75 & 3 & $18,25 \%$ & 2 & $12,5 \%$ \\
4. & BB & 8 & $50 \%$ & - & - & - & - \\
\hline
\end{tabular}

Penelitian penerapan pembelajaran gerak tari ayam di TKIT Mutiara Hati Petarukan ini menunjukkan adanya peningkatan kemampuan motorik kasar. Gerak tari ayam dipilih karena gerakannya yang mudah dipahami dan diingat anak. Pelaksanaan penelitian ini didesain dalam dua siklus, dimana setiap siklus terdiri dari dua tatap muka. Perubahan kemampuan motorik kasar anak terjadi dari tahapan awal, siklus 1 dan siklus II. Perubahannya selalu menunjukkan adanya peningkatan, meskipun pada awal pembelajaran gerak tari ayam disajikan tanpa menggunakan iringan musik pengemasan pembelajaran melalui gerak tari ayam membuat anak tertarik. Pembelajaran pada anak usia dini dapat dilaksanakan dengan baik, jika gurunya memiliki kompetensi pedagogi yang bagus pula (Sum dan Taran, 2020).

Selain mampu meningkatkan kemampuan motorik kasar anak, gerak dan tari yang dilaksanakan dalam suatu kelompok atau komunitas teman diharapkan dapat menunjang 
kemampuan anak dalam hal kemampuan sosial dan emosional. Tari yang dimaknai sebagai pengungkapan perasaan manusia melalui gerakan yang sesuai dengan ritme (Mulyani, 2016), membuat tari gemar disukai anak. Gerakan tubuh yang sesuai dengan ritmis pada anak usia dini menunjang perkembangan fisik motorik. Selain meningkatkan ketrampilan motorik, tari juga dapat meningkatkan ketrampilan sosial anak (Mulyasari, dkk. 2020).

\section{SIMPULAN DAN SARAN}

Berdasarkan hasil penelitian dapat diambil kesimpulan bahwa kemampuan motorik kasar anak usia dini Kelompok B1 TKIT Mutiara Hati Petarukan meningkat melalui pembelajaran gerak tari ayam. Pada setiap pembelajaran gerak tari ayam yang didesain dua siklus, anak usia dini kelompok B1 TKIT Mutiara Hati Petarukan meningkat kemampuan motorik kasarnya. Tercapainya indikator keberhasilan diatas target peneliti 75\% yakni dengan perolehan presentase $81,25 \%$ pada kategori anak berkembang sangat baik (BSB).

Guru merupakan pemeran utama dalam dunia pendidikan untuk meningkatkan perkembangan peserta didiknya seorang guru haruslah menjadi pribadi yang kreatif, menyenangkan, dan profesional dalam mendidik peserta didiknya. Pelaksanaan pembelajaran harus dibuat semenarik mungkin dengan mengevaluasi setoap kekurangan agar mudah diterima oleh peserta didik. Pembelajaran untuk anak usia ini hendaknya selalu dikemas dengan baik dan disesuaikan dengan tahapan perkembangannya, sehingga anak menjadi mudah tertarik, antusias, dan mudah memahaminya.

\section{DAFTAR PUSTAKA}

Akbar, Eliyyil, dan Jainal Abidin. Pembelajaran Seni Tari dalam Mewujudkan Aspek Perkembangan Anak di Taman Kanak-Kanak Peteri Bensu Takengon. Jurnal Pendidikan Anak: AWLADY. Vol. $4 . \quad$ No. 2. http://dx.doi.org/10.24235/awlady.v4i2.3221

Alawiyah, Tuti Ratu. 2014. Peningkatan Ketrampilan Motorik Kasar Anak Melalui Permainan Tradisional Banten. Jurnal Pendidikan Usia Dini. Vol 8. No (1).

Anggraini, W., \& Kuswanto, C. W. (2019). Teknik Ceklist Sebagai Asesmen Perkembangan Sosial Emosional di RA. Al-Athfaal: Jurnal Ilmiah Pendidikan Anak Usia Dini, 2(2), 61-70. https://doi.org/10.24042/ajipaud.v2i2.5248

Apriloka, Dinita Vita. 2020. Keterampilan Motorik Kasar Anak Usia Dini Ditinjau Dari jenis Kelamin. JAPRA: Jurnal Pendidikan Raudhatul Athfal. Vol. 3. No. 1.

Arikunto, Suharsimi. Dkk. 2011. Penelitian Tindakan Kelas. Jakarta: PT. Bumi Aksara 
Arwati, Ni Made, dan Siti Fadillah. 2019. Pengaruh Gerak Dan Lagu (Music And Movement) terhadap Peningkatan Kosakata Bahasa Inggris pada Anak Usia 5-6 Tahun di PAUD Kasih Ibu. PAUD Lectura: Jurnal Pendidikan Anak Usia Dini. VOL. 2. No. 2. https://doi.org/10.31849/paud-lectura.v2i02.2514

Febrialismanto. 2017. Gambaran Motorik Kasar Anak Usia 4-5 Tahun di Taman Kanak-kanak Kecamatan Bangkinang Kabupaten Kampar Provinsi Riau. Jurnal Pesona Dasar. Vol 5. No (2).

Hasanah, Uswatun. 2016. Pengembangan Kemampuan Fisik Motorik Melalui Permainan Tradisional Bagi Anak Usia Dini. Jurnal Pendidikan Anak. Vol 5. No. 1.

Hidayanti, Maria. 2013. Peningkatan Kemampuan Motorik Kasar Anak Melalui Permainan Bakiak. Jurnal Pendidikan Anak Usia Dini. Vol 7. No (1).

Kardiawarman. 2000. Penelitian Tindakan Kelas (PTK). Bandung: Unoversitas Pendidikan Indonesia.

Khoiruzzadi, Muhammad, dkk. 2020. Upaya Guru dalam Memaksimalkan Perkembangan Kognitif, Sosial dan Motorik Anak Usia Dini. JECED. Vol. 2. No. 1. https://doi.org/10.15642/jeced.v2i1.561.

Kuswanto, C. W. (2016). Menumbuhkan Kemandirian Anak Usia Dini Melalui Bermain. Jurnal Ilmiah Pendidikan Islam Anak Usia Dini Darul Ilmi, 1(2).

Mulyani, Novi. 2016. Pendidikan Seni Tari Anak Usia Dini. Yogyakarta: Gava Media.

Mulyasa. 2012. Manajemen PAUD. Bandung: PT Remaja Rosdakarya.

Mulyasari, dkk. 2020. Peningkatan Keterampilan Sosial Melalui Kegiatan Tari Saman. Jurnal Obsesi: Jurnal Pendidikan Anak Usia Dini. Vo. 4 No. 2. https://doi.org/10.31004/obsesi.v4i1.240

Mulyani, Novi. 2017. Pengembangan Seni Anak Usia Dini. Bandung: Rosda.

Novitasari, Reni, dkk. 2019. Meningkatkan Kemampuan Motorik Kasar Anak Melalui Bermain dengan Media Hulahoop Pada Anak Kelompok B PAUD Al-Syafaqoh Kabupaten Rejang Lebong. Jurnal Ilmiah Potensia. Vol. 4. No. 1.

Padilah dan Novianti. 2019. Implementasi Kegiatan Bermain Papercraft dalam Meningkatkan Kemampuan Motorik Halus Anak Kelas B PAUD Taman Sari Banyuasin. PAUD Lectura: Jurnal Pendidikan Anak Usia Dini. VOL. 3. No. 1. https://doi.org/10.31849/paud-lectura.v3i01.3273

Putri, Meylani Eka, dan Prima Aulia. 2020. Efektivitas Permainan Lari Estafet Modifikasi Untuk Menignkatkan Motorik Kasar Pada Anak di Taman Kanak-Kanak Bahari Pasir Kandang. Jurnal Pendidikan Anak: Bunayya. Vol. 6. No. 1.

Rahyubi, Heri. 2012. Teori-teori Belajar dan Aplikasi Pembelajaran Motorik Deskripsi dan Tinjauan Kritis. Majalengka: Nusa Media. 
Rofiah, Sohibah Darojatur dan Hilman Mangkuwibawa. 2020. Upaya Meningkatkan Kemampuan Motorik Halus Anak Melalui Kegiatan Memabtik Jumputan. JAPRA: Jurnal Pendidikan Raudhatul Athfal. Vol. 3. No. 1.

Standar Tingkat Pencapaian Perkembangan Anak (STTPA) PAUD Kurikulum 2013.

Sum, Theresia Alviani dan Emilia Greceila Mega Taran. 2020. Kompetensi Pedagogik Guru PAUD dalam Perencanaan dan Pelaksanaan Pembelajaran. Jurnal Obsesi: Jurnal Pendidikan Anak Usia Dini. Vo. 4 No. 2. https://doi.org/10.31004/obsesi.v4i2.287

Suryana, Dadan. 2016. Pendidikan Anak Usia Dini Stimulasi dan Aspek Perkembangan Anak. Jakarta: Kencana.

Rachmi, Tetty dkk. 2018. Ketrampilan Musik dan Tari. Tangerang Selatan: Universitas Terbuka.

Zahroh, Amilatul dkk. 2019. Peningkatan Keterampilan Motorik Kasar Melalui Alat Permainan Simpai pada Anak Kelompok A di Taman Kanak-Kanak Dharma Wanita Bangun Ungging Mojokerto. JECED. Vol 1. No. 1. https://doi.org/10.15642/jeced.v1i1.493.

Zarkasih, Muslichah dan Tjandrasa Meitasari. 1978. Perkembangan Anak Jilid I. Jakarta: Erlangga. 